Gadjah Mada International Journal of Business

January 2003, Vol. 5, No. 1, pp. 57-77

\title{
TAX COSTS AND CORPORATION DIVIDEND POLICY Evidence from the 1986 U.S. Tax Reform Acts
}

\author{
Siddharta Utama
}

Scholes and Wolfson (1992) predict that following the 1986 Tax Reform Act, the tax cost of the corporate form relative to that of the partnership form (the incremental tax cost) increased significantly. This study hypothesizes that since dividends represent a tax disadvantaged form of income relative to capital gains, then in response to an increase in incremental tax costs, corporations would decrease their dividend payout ratios. The response is expected to be stronger for corporations owned by shareholders with long investment horizons because the tax cost saved from decreasing dividend payout ratios is an increasing function of shareholders' investment horizon. The empirical tests support the hypothesis and show a negative relationship between the change in incremental tax costs and the change in dividend payout ratios for firms with long average investment horizons.

Keywords: dividend policy; organizational form; tax cost; tax reform act 


\section{Introduction}

This study examines the change in dividend payout ratio across a sample of NYSE/AMEX corporations in response to the 1986 Tax Reform Act. It also investigates whether the response depends on the average holding period of corporations' shareholders.

There are significant differences in tax treatment across different legal organizational forms. One important example is the difference in the tax cost of corporate and partnership form. Tax costs are defined as the sum of the income taxes imposed on the organization and any taxes imposed on the equity owners of the organization (Guenther 1992). Corporate income attributable to stockholders is subject to double taxation. The tax costs consist of the corporate income tax and the shareholders' tax on dividend income and capital gains. On the other hand, partnership income is subject to only one level of taxation. The tax costs are the personal taxes paid on the taxable income of the partnership. However, despite their tax disadvantages, corporations enjoy lower transaction costs over partnership. The lower transaction costs includes lower operating costs, better access to capital markets, and better control of management (Scholes and Wolfson 1992).

According to Scholes and Wolfson (1992), a firm chooses an organization's form to minimize both tax costs and transaction costs. When the corporate form has a greater tax cost than the partnership, the corporate form would only be chosen if the transaction costs of the partnership form exceed those of the corporate form. A new tax rule may change the relative tax costs of corporations over partnerships. This change may result in firms' conversion in form. Absent this conversion, firms may adopt new operational and/or financial policies that minimize tax costs and transaction costs.

In line with this, Scholes and Wolfson (1992: 68-69) predict that after the 1986 tax reform act (TRA), the tax cost of the corporate form increases substantially relative to that of the partnership form. There are two reasons for the increase:

1. The reduction of top personal tax rates from 50 percent to 28 percent is larger than the reduction of the top corporate tax rate, which drops from 46 percent to 34 percent.

2. The shareholder level tax on after-tax corporate profits has increased substantially. This is due to the reduction of the capital gains exclusion from 60 percent to 0 percent.

The prediction leads directly to the question of responses of corporations to the increasing tax costs. One response that corporations can make is to alter their dividend policy. A finding that there is a change in dividend policy in response to the increase in tax cost would provide evidence of the relevance of dividend policy on minimizing tax costs. Thus, this study attempts to shed light on the relevance of dividend policy by investigating whether there is any systematic change in dividend policy in reaction to the increase in tax cost.

Since dividends represent a tax disadvantaged form of income relative to capital gains, corporations are predicted to respond to an increase in tax costs by decreasing dividend payout ratios. The tax cost saved from decreasing dividend payout ratios is an increasing function of shareholders' investment horizons. Therefore, the response is expected to be stronger for corporations owned by shareholders with long investment horizons. 
Utama-Tax Costs and Corporation Dividend Policy

This study is similar to a study by Guenther (1992) that investigated the response of corporations to the 1981 Economic Recovery Tax Act (ERTA). Guenther asserts that ERTA caused an increase in the tax costs of the corporate form relative to those of the partnership form. This study differs from Guenther (1992) in that it examines the change in dividend policy of corporations as a result of the 1986 TRA. In addition, it demonstrates that the change in dividend policy depends on the investment horizon of corporations' shareholders.

Previous studies predict that the TRA is likely to induce firms to raise their dividend payout ratios. The reason is that the TRA makes dividend income less heavily taxed and equalizes the statutory tax rates on dividends and capital gains. Evidences of the impact of the 1986 TRA on dividend policy have been mixed. Some studies (Gordon and MacKie Mason (1991), Papaioannou and Savarese (1994) find that dividend payout ratios significantly increase following the TRA, while one study (Bolster and Janjigian 1991) finds no significant difference between the pre- and the post-TRA mean aggregate dividend payout ratios for a large sample of firms. The studies, however, do not control the impact of the increase in tax costs on dividend policy. This may bias the results. This study differs from previous studies in that it takes into account the impact of the increase in tax costs on dividend policy.

To measure the relative tax cost of the corporate form to that of the partnership form (i.e., the incremental tax costs), this study follows Guenther's measurement of incremental tax costs. Guenther employs two measures of incremental tax costs. He assumes either that capital gains tax can be postponed indefinitely (the lower bound measure) or that all capital gains are taxed currently (the upper bound measure). This study extends Guenther's study by proposing a measurement of incremental tax costs that considers the length of holding period in determining the present value of the capital gains tax.

The results of this study show that there is a negative relationship between the change in incremental tax costs and the change in dividend payout ratios. The relationship is stronger for firms with longer average investment horizons. In addition, after controlling the effect of the change in incremental tax costs and the pre- 86 average payout ratios, the study finds that corporations significantly increase their payout ratios. Finally, the results of this study show that the lower bound and the upper bound incremental tax costs that are used by Guenther are subject to measurement bias.

The remainder of the study is organized as follows. The first section provides literature review relevant to this study and develops hypotheses dealing with the objectives of the study. The second section presents the measurement of the variables used in the empirical tests as well as the sample selection procedure. The third section reports the results of comparisons of alternative incremental tax cost measures. The fourth section provides the results of testing the hypotheses and the last section contains a conclusion. The appendix compares alternative tax wedge measures.

\section{Literature Review and Hypothesis Development}

Following is a summary of theories of dividend policy that have been developed in the past. The Miller and Modigliani (1961) paper proves the irrelevance of dividend policy in a world where there are 
no taxes or transaction costs. Once corporate and personal income taxes are introduced, the theory (e.g. Brennan 1970) suggests that it would be optimal to pay no dividends at all because of the tax disadvantage of dividends relative to capital gains. Yet, contrary to the theory, corporations do pay dividends. The Barclay and Smith (1995) paper suggests that there appears to be strong cross-sectional regularities in dividend payout. Accordingly, there may be optimal dividend policies that result from a trade-off between the costs and benefits of paying dividends. Copeland and Weston (1992) summarize the possible cost and benefits of dividends as follows. The possible costs includes (1) the tax disadvantages of receiving income in the form of dividends rather than capital gains, (2) the cost of raising external capital if dividends are paid out, and (3) the foregone use of funds for productive investment. The possible benefits are (1) higher perceived corporate value because of the signaling content of dividends, (2) lower agency costs of external equity, and (3) the ability of dividend payments to help complete the markets. Thus, the tax cost of dividends is only one consideration in choosing a dividend policy.

With the enactment of the 1986 tax reform act, the top personal tax rates were reduced from 50 percent to 28 percent while the top corporate tax rate dropped from 46 percent to 34 percent. The capital gains exclusion was also reduced from 60 percent to 0 percent. The TRA has direct and indirect impact on corporate dividend policy. The direct impact is through the increased attractiveness of dividend relative to capital gain, while the indirect impact is through the response of corporations to the increase in the incremental tax cost after 1986 .
Following the TRA, there is an increase in the tax burden on capital gains and the reduction in the tax burden on dividend income. This makes dividends more attractive as the source of income. On the basis of this assertion, Ben-Horin, Hocman and Palmon (1987) predict that dividend payout ratios should increase in the post-TRA period.

All previous studies only focus on the direct impact of the TRA on dividend policy. The studies predict that corporate dividend payout ratios should increase in response to the TRA. The results of the studies have been mixed. Gordon and Mackie-Mason (1990) uncover a substantial increase in payouts from 1984 to 1988. However, they employ aggregate data in that the payout ratio is defined as the aggregate dividends of corporations divided by aggregate after tax profits of corporations. The aggregate payout ratio, therefore, is biased toward large corporations. Based on the mean and the median aggregate dividend payout ratios, Bolster and Janjigian (1991) find no evidence that dividend payouts increase in response to tax reform. Their results are consistent with Abrutyn and Turner (1990) who find that 85 percent of corporations surveyed did not expect to change payouts in response to the TRA.

Papaioannou and Savarese (1994) employ a matched-pairs design to test whether the pre-TRA average payout ratios are significantly different from the post-TRA average payout ratios. The test indicates that there is no significant change during the period. They then divide the sample firms into five quintiles according to their pre-TRA average dividend payout ratios and repeat the matched-pairs t-tests for each quintile. They find that firms with low and medium payout ratios in the pre- 
Utama-Tax Costs and Corporation Dividend Policy

TRA period increased their payout ratios significantly after 1986 while firms in the highest payout ratio group experience a significant decline in their payout ratios. They interpret the findings to be supportive of the prediction. Their findings, however, can also be interpreted as the reflection of mean reversion of dividend payout ratios. Firms with low payout ratios tend to increase their payout ratios since they have capacity to do so while firms with high payout ratios tend to decrease their high ratios toward their lower long-term target payout ratios.

The indirect impact of the TRA on dividend policy is explained as follows. Scholes and Wolfson (1992: 58) show that, ignoring non-tax considerations and assuming no dividend payment, a taxpayer will be indifferent between a partnership and a corporation whenever the following equation holds:

$$
\begin{aligned}
& {\left[1+\mathrm{R}\left(1-\mathrm{t}_{\mathrm{p}}\right)\right]^{\mathrm{n}}=} {\left[1+\mathrm{R}\left(1-\mathrm{t}_{\mathrm{c}}\right)\right]^{\mathrm{n}}\left(1-\mathrm{gt}_{\mathrm{p}}\right)+} \\
& \mathrm{gt}_{\mathrm{p}} \ldots \ldots \ldots \ldots \ldots \ldots \ldots \ldots \ldots \ldots \ldots \ldots \ldots \ldots \ldots \ldots \ldots \ldots \\
&
\end{aligned}
$$

where,

$\mathrm{R}=$ the before tax return on investment,

$\mathrm{t}_{\mathrm{p}}=$ the personal tax rates,

$\mathrm{t}_{\mathrm{c}}^{\mathrm{p}}=$ the corporate tax rate,

$\mathrm{g}=$ the capital gain inclusion rate on gains

from sale of shares and $\mathrm{n}$ is the time period of the investment.

The left side of the equation is the after-tax accumulation on an initial $\$ 1$ investment for a partnership, and the right side of the equation is that for a corporation. The incremental tax cost of the corporate form over the partnership form is greater than zero (i.e., the partnership is preferred) if the after-tax accumulation for a partnership is higher than that for a corporation.
From Equation 1, after 1986 the partnership form dominates the corporate form since $t_{p}<t_{c}$ and $g=1$. Even if corporations can defer indefinitely the payment of the capital gains tax (i.e., $g=0$ ), partnerships still dominate corporations for many profitable firms as long as $t_{p}<t_{c}$. In conclusion, if everything else remains constant (dividends, earnings, etc.), on average, corporations should have experienced increased incremental tax costs after 1986.

As a consequence of the 1986 Tax Act, from a tax consideration, many corporations would convert to the partnership form. However, relatively few corporations changed to the partnership form, both because of perceived non-tax advantages of the corporate form and due to the costs of converting from the corporate form. Given this, corporations might be expected to take certain actions that would reduce the increase in their incremental tax costs.

Consistent with the theory of the tax disadvantage of dividends, one response of corporations to increasing tax costs of the corporate form is to decrease the dividend payout ratio. By decreasing the dividend payout ratio and increasing retained earnings, corporations are able to postpone the personal taxes assessed on shareholders because retained earnings are taxable only after they are realized by shareholders. This would reduce the increase in the relative tax costs of the corporate form. Since there is a trade-off between the costs and benefits of paying dividends, corporations would reduce the dividend payout ratios to the point where the additional tax savings equal the incremental cost of reducing them. Thus, the indirect impact of the TRA is that dividend payout ratios should decrease in response to an increase in tax costs. 
After 1986, with capital gains fully taxable at ordinary rates, investors retain the advantage only of the deferral of capital gain taxes for the length of the holding period. Tax deferral becomes more valuable as the holding period of investors gets longer. Accordingly, the tax costs saved from decreasing dividend payments is an increasing function of investors' holding periods. Therefore, the negative association between the change in corporations' relative tax costs and the change in their dividend payout ratios is expected to be stronger for corporations whose investors have relatively long holding periods. ${ }^{1}$ Thus, the negative association between the change in the incremental tax cost and the change in the dividend payout ratio is stronger for corporations whose investors have long holding periods.

There has been no study that investigates the indirect impact of the 1986 TRA on dividend policy. Guenther (1992) examines the effect of the 1981 individual tax reductions on the incremental tax cost of the corporate form. With ERTA, the maximum tax rate on partnership form decreased from 70 to 50 percent, while the maximum corporate rate remained unchanged. Therefore, corporations should have experienced increased incremental tax costs after 1981. The results of his tests are consistent with this prediction. He also finds that there is a negative correlation between the change in the dividend payout ratios and the change in the incremental tax costs following ERTA.

The direct and indirect impacts of the TRA on dividend policy generate conflicting prediction. In combination, it may appear that corporations' dividend policy does not respond to the TRA while it actually does. This may also explain why some studies do not find significant change in dividend payout ratios after 1986 . This study attempts to investigate both direct and indirect impacts of the TRA on dividend policy. Hereafter, I label the prediction of the direct impact of the TRA as the direct impact hypothesis while the prediction of the indirect impact of the TRA as the indirect impact hypothesis.

\section{Measurement of Variables and Sample Selection}

\section{Measurement of Variables}

The variables of the study are similar to those of Guenther's study (1992) with some modifications. Guenther (1992) defines incremental tax cost as the difference between the tax cost of the corporate form and the tax cost of the partnership form. According to the definition, the incremental tax cost of the corporate form [i.e., tax wedge $(\mathrm{W})]$ is as follows:

$$
\mathrm{W}=\mathrm{TI}\left(\mathrm{t}_{\mathrm{c}}\right)-(\mathrm{TI}-\mathrm{D})\left(\mathrm{t}_{\mathrm{p}}\right)+\frac{\mathrm{UNI}\left(\mathrm{gt}_{\mathrm{p}}\right)}{(1+\mathrm{i})^{\mathrm{n}}}
$$

$t c, t p$, and $g$ are as defined previously

$\mathrm{TI}=$ the taxable income,

$\mathrm{D}=$ the amount paid as a dividend,

$\mathrm{UNI}=$ the undistributed net income,

$\mathrm{i} \quad=$ the investor discount rate, and

$\mathrm{n}=$ the number of years that the investor holds the stock before the capi-

\footnotetext{
${ }^{1}$ As another response to the tax act, investors could change their holding periods. However, tax cost is only one of many factors to consider in setting up investors' investment strategies, and therefore, investors have to take account these factors to evaluate the trade-off between the costs and benefits from changing their holding periods. The focus of this paper is on the response of corporations and not the response of investors.
} 
Utama-Tax Costs and Corporation Dividend Policy

tal gain is taxed (i.e., the investment horizon/holding period).

The equation states that the tax wedge is equal to the corporation income tax $\left[\mathrm{TI}\left(\mathrm{t}_{\mathrm{c}}\right)\right]$, less the investors' tax avoided on undistributed taxable income [(TI-D)(tp)] the present value of the capital gains tax due upon a future sale of the shares $\left[\mathrm{UNI}(\mathrm{gtp}) /\left({ }_{1+} \mathrm{i}\right)^{\mathrm{n}}\right]$. A positive tax wedge implies that the tax cost of the corporate form is higher than the tax cost of the partnership form.

Guenther employs two measures of tax wedges. The first measure, the lower bound tax wedge, assumes that the capital gains tax can be deferred indefinitely; therefore, the present value of the future tax is close to zero and can be ignored [i.e., $\left.\mathrm{UNI}\left(\mathrm{gt}_{\mathrm{p}}\right) /(1+\mathrm{i})^{\mathrm{n}}=0\right]$. The second measure, the upper bound tax wedge, assumes that shareholders realize their capital gains in the current year, so all capital gains are taxed currently (i.e., $\mathrm{n}=0$ ).

The two measures are subject to systematic measurement bias. The lower bound measure tends to understate the tax wedge, while the upper bound measure tends to overstate the tax wedge. ${ }^{2}$ Further- more, the lower bound tax wedge does not capture the effect of the elimination of the capital gain inclusion rate (i.e., g increases from 0.4 to 1 ) because the effect can be captured only if the last term of Equation 2 does not equal zero. The effect of the assumption is to understate the increase in the tax wedge and bias the results against finding a significant increase in the tax wedge after 1986. The upper bound tax wedge, on the other hand, tends to overstate the increase in the tax wedge and to bias the results for finding an increase in the tax wedge after 1986.

To overcome the above limitations, in addition to using the upper bound and lower bound tax wedges, this study uses a third tax wedge measure, the within bound tax wedge, that captures shareholders' average holding period (n) in the calculation of the tax wedge. To estimate the average holding period ( $\mathrm{n}$ ) for a corporation, the study defines the average holding period as the total outstanding shares of the corporation divided by the total shares traded in one year for that particular firm. ${ }^{3}$ The definition implies that higher market liquidity is associated with a shorter investment horizon.

${ }^{2}$ The difference between the tax wedge in Equation (2) and the lower bound measure is the present value of the future tax. The measure becomes more understated as net income(NI) is higher, the dividend is lower, the discount rate is lower and the average holding period is shorter. The difference between the upper bound measure and the tax wedge in Equation (2) follows:

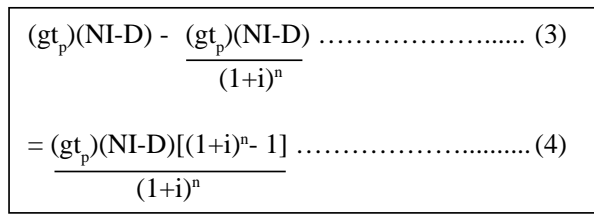

where NI is net income.

The upper bound measure becomes more overstated as net income is higher, the dividend is lower, the discount rate is higher, and the average holding period is longer.

${ }^{3}$ For example, if a corporation has 1000 shares outstanding in a certain year and the shares trading volume of that year is 200 shares, then the average holding period of shareholders of the corporation for that year is estimated to be 5 year. 
Throughout the balance of the paper, the lower bound, upper bound and within bound tax wedges are referred to LOWER WEDGE, UPPER WEDGE, and WITHIN WEDGE respectively. The appendix compares these three measures of incremental tax costs.

The study adopts the definitions of taxable income and tax liability that are used by Stickney and McGee (1981) in which the corporation income tax includes federal, foreign and state taxes. Tax liability is calculated as total tax expense minus the deferred tax expense reported on the income statement. The taxable income is defined as the pretax book income minus the deferred tax expense reported on the income statement.

The investor tax rate (tp) is defined consistent with Guenther. The method calculates a weighted average investor marginal tax rate assuming that the composition of investor groups does not differ across firms. The source of information is

\section{Table 1. Weighted Aveage Marginal Tax Rates for Individuals Re- ceiving Dividend Income}

\begin{tabular}{ccc}
\hline Year & & Tax Rate \\
1984 & & $35.19 \%$ \\
1985 & & $34.98 \%$ \\
1986 & & $35.98 \%$ \\
1987 & & $28.75 \%$ \\
1988 & & $24.91 \%$ \\
1989 & & $24.73 \%$ \\
\hline
\end{tabular}

from the Internal Revenue Service publication Statistics of Income. Table 1 provides the weighted average marginal tax rates for each year from 1984 through 1989. ${ }^{4}$ 'The undistributed netincome(UNI) is defined as the difference between net income and dividend. ${ }^{5}$

The discount factor, or the cost of equity (i) is estimated using the capital asset pricing model:

$$
i_{i}=r_{f}+b\left(r_{m}-r_{f}\right)
$$

where

$\mathrm{i}_{\mathrm{i}}=$ the cost of equity for firm $i$,

$r_{\mathrm{f}}=$ the risk free rate,

$r_{m}=$ the required market rate of return and $b_{i}$ is beta for firm $i$.

Consistent with other studies, the average rate on long-term Treasury bonds is used as the proxy for the risk free rate. The study uses the yield on a 10-year Tbond and the rates are taken from the Federal Reserve Bulletin.

The market risk premium $\left(r_{m}-r_{f}\right)$ is estimated based on ex post, or historical returns. The most thorough and widely publicized ex post risk premium study is conducted annually by Ibbotson Associates, who examine market data over long periods of time to find the average annual rates of return on stocks, T-bills, T-bonds, and a set of high-grade corporate bonds. The study uses Ibbotson's data and defines the risk premium as the average premium of stocks over T-bonds. The data indicate that over the 63-year period from 1926 to 1988 , the average premium of stocks over

\footnotetext{
${ }^{4}$ The study employs multi-year period because the full effect of the tax law change on the response of corporations is expected to span for several years. Except for the 1986 Tax Reform Act, during 1984-1989 there was no major tax law change that might confound the test results.

${ }^{5}$ UNI can be negative, implying that capital losses occur. A negative UNI does not change the hypotheses because corporations can still avoid personal taxes on dividends by decreasing dividend payout ratios. However, from investors' standpoint, it would be more tax advantageous to recognize the losses as they occur rather than to postpone the realization of the losses. This is different from capital gains where it is more tax advantageous to postpone the realization of the gains.
} 
Utama-Tax Costs and Corporation Dividend Policy

Table 2. Measurement of Variables

(Including COMPUSTAT Data Item Numbers)

Corporation Income Tax [TI (tc)]:

Total Tax Expense minus Deferred Tax Expense

(\#16 - \#50)

Taxable Income (TI):

Pretax Book Income minus (DTL/SMTR)

$[\# 18+\# 16+\# 49-(\# 50 /$ SMTR $)]$

Dividend (D):

Cash Dividend (\#21)

Undistributed Earnings (UNI) :

Net Income minus Dividend

$(\# 18$ + \#49 + \#50 - \#21)

Average Holding Period (n):

Outstanding Shares / Shares Traded in one year

(\#25 / \#28)

Legend:

DTL = Deferred Tax Liability

SMTR = Statutory Marginal Tax Rate

$1984-86=0.46 ; \cdot 1987=0.40 ; 1988-89=0.34$

\# = COMPUSTAT Data Item number

T-bonds was 7.4 percent. Assuming that the risk premium during 1984-1989 is the same as the risk premium during 19261988 , the study uses 7.4 percent as the estimated risk premium for 1984 to 1989 . Due to data limitations, beta is taken from COMPUSTAT.

Consistent with previous studies, the dividend payout ratio is calculated as the sum of common dividends divided by the net income. Table 2 presents the measurements of the variables and their COMPUSTAT data item numbers.

\section{Sample Selection Procedure}

The sample corporations are all New York Stock Exchange and American Stock
Exchange COMPUSTAT corporations and are not in the extractive industries, utilities, financial institutions and insurance SIC classifications. ${ }^{6}$ In addition, the sample excludes firms meeting any one of following criteria: (1) incorporation outside of the United States; (2) other than a calendar year end; (3) missing financial statement information; and (4) having an average dividend payout ratio greater than zero over 1984-86.

Corporations in utilities, financial institutions, insurance, and the extractive industries are not used because of the presence of unique tax rules available only to those industries. The first criterion eliminates firms that are domiciled abroad so

\footnotetext{
${ }^{6}$ OTC firms are excluded from the sample corporations because the COMPUSTAT data for many of these firms are incomplete and inaccurate.
} 
Gadjah Mada International Journal of Business, January 2003, Vol. 5, No. 1

Table 3. Sample Selection Statistics for he Sample of Corporations

\begin{tabular}{|c|c|}
\hline $\mathbf{a}$ & \\
\hline \multirow{2}{*}{$\begin{array}{l}\text { Initial COMPUSTAT sample } \\
\text { Less : Firms in the extractive industries, utilities, } \\
\text { financial institutions and insurance industry } \\
\text { classification }\end{array}$} & 2435 \\
\hline & $\begin{array}{r}937 \\
1498\end{array}$ \\
\hline $\begin{array}{l}\text { Less : Firms with incorporations other than } \\
\text { the United States }\end{array}$ & $\begin{array}{r}94 \\
1404\end{array}$ \\
\hline Less : Firms with other than a calendar year end & $\begin{array}{l}630 \\
774\end{array}$ \\
\hline $\begin{array}{l}\text { Less : Firms with missing information: } \\
\text { Final Sample Size : }\end{array}$ & $\begin{array}{l}406 \\
368\end{array}$ \\
\hline Final Sample Size : & 368 \\
\hline
\end{tabular}

$\mathrm{a}=$ Includes only firms from the COMPUSTAT on the New York Stock Exchange and American Stock Exchange

more consistent and reliable estimates of taxable income and corporate income tax can be secured. The second criterion is necessary since, as Guenther (1992: 28) notes, "The equation for the tax wedge assumes that dividends (paid) will be taxed at the same marginal investor tax rate as partnership income would be, and this assumption will not hold for fiscal year corporations if investor tax rates differ across calendar years." The last criteria is needed because the indirect impact hypothesis is applicable only for firms that pay dividends before 1986.The effect of each of the criteria on the sample size is presented in Table 3.

Because of the apparent growth in firm size over the sample period, and to eliminate the effect of the growth from the tax wedge measures, the tax wedge is scaled by total sales.

\section{Empirical Results}

\section{Univariate Test}

This section investigates whether the average tax wedge change is greater than zero and whether the average change in dividend payout ratio is significantly different from zero.

The study calculates the average tax wedge $\left(\mathrm{Wi}^{*}\right)$ for each sample corporation $i$ over two sub-periods, 1984-86 and 198789 using three alternative tax wedge measures. To get the change in the tax wedge, the difference between these two averages is calculated for each sample corporation $i$ by subtracting $W i^{* 1984-86}$ from $W i^{* 1987-89}$. Then the mean of these differences is calculated.

The results of the test for the average tax wedge change are shown in Table 4, 
Utama-Tax Costs and Corporation Dividend Policy

panel A. The average of the change in the average tax wedges is significantly greater than zero for WITHIN WEDGE and UP$P E R$ WEDGE, but it is not significant for LOWER WEDGE. ${ }^{7}$ LOWER WEDGE provides the lowest mean or median and $U P$ PER WEDGE generates the highest mean or median, confirming the discussion in Section III.1 (measurement of variables) that they provide the lower bound and upper bound of tax wedge change. The findings generally confirm Scholes and Wolfson (1992) prediction and indicate that, on average, the 1986 tax law change resulted in an increase in the tax cost of the corporate form.

The average payout ratio is calculated for each sample corporation over two sub-periods, 1984-86 and 1987-89. ${ }^{D I V C H G}{ }_{i}$ is the difference between these two averages for each sample corporation $i$. To control for extreme outliers that may bias the results, I eliminate 10 percent of firms with extreme low or high dividend changes. These restrictions reduce the sample size to 209 corporations.

The result of the univariate test is reported in Table 4 panel B. The average payout ratios have not significantly changed over the period. The result is consistent with the finding of Papaioannou and Savarese (1994). The univariate test, however, conceals the direct and the indirect impact of the TRA as they may offset each other.

\section{Multivariate Test}

This section investigates the change in dividend payout ratio after controlling for the effect of the tax wedge change. The study employs six measures of tax wedge change. The first three measures are the original measures defined in Section III.1 (measurement of variables). The other three measures are "as if" tax wedge changes based on LOWER, WITHIN, and UPPER $W E D G E$ measures. The original tax wedges are all calculated with the actual data for each year in the sample period. If firms decrease dividends in response to higher tax costs, the effect of the response on the tax wedge is a reduction in the increase in the tax wedge caused by the tax law change. This will reduce the association between the responses and the increase in the observed tax wedges. In order

Table 4. Univariate Test

\begin{tabular}{lccrrrrr}
\hline & $\begin{array}{c}\text { Sample } \\
\text { Size }\end{array}$ & & Mean & & t-Stat & p-Value & Median \\
\cline { 2 - 2 } Panel $\boldsymbol{A}$ & & & & & \\
LOWER WEDGE & 368 & & 0.0008 & 0.562 & 0.288 & 0.0031 \\
WITHIN WEDGE & 368 & 0.0033 & 2.74 & 0.0032 & 0.0042 \\
UPPER WEDGE & 368 & 0.0037 & 3.098 & 0.0011 & 0.0045 \\
Panel B & & & & & \\
DIVCHG & 208 & -0.0429 & -2.683 & 0.004 & -0.0116 \\
\hline
\end{tabular}

P-values are based on one-tailed tests

\footnotetext{
7 The sign test, however, indicates that the tax wedge change for LOWER WEDGE is greater than zero at 1 percent level. For 368 sample firms, 243 firms have tax wedge change greater than zero.
} 
to remove the effect of the responses, an "as if" wedge is calculated for each firm in the sample for the years 1987-1989. In general, the "as if" tax wedge is calculated by assuming that the response variable being investigated remained at its average 1984-86 after 1986.

The "as if" dividend payout ratio is calculated by assuming that each firm's dividend payout ratio for 1987-1989 is equal to the firm's mean dividend payout ratio for 1984-1986. This "as if" dividend payout ratio is multiplied by the taxable income for each year of 1987-1989 to arrive at an "as if" dividend amount for the same years. The "as if" dividend amount is then used in the tax wedge calculation. The measure of "as if" tax wedge as defined above, together with the ordinary tax wedge, is used to measure the change in tax wedge.

The following regression model (Model 1) is used to test the hypotheses:

DIVCHG $_{\mathrm{i}}=\mathrm{b}_{0}+\mathrm{b}_{1}$ WEDGECHG $_{\mathrm{i}}+$

$$
b_{2} \operatorname{AVGPAY}_{\mathrm{i}}+\mathrm{e}_{\mathrm{i}} \ldots(6)
$$

where,

$\mathrm{i}=$ for the $i^{\text {th }}$ firm,
PAYCHG $=$ the change in the dividend payout ratio,

WEDGECHG = the "as if" tax wedge change or the tax wedge change,

AVGPAY $=$ the average dividend payout ratio ${ }_{1984-86}$, and $\mathrm{e}$ is the residual term.

The average dividend payout ratio is used to control for the dividend capacity of a firm. Firms that have high payout ratios are more likely to reach their capacity to pay dividends and therefore cannot substantially increase their payout ratios. Hence, its coefficient is expected to be negative.

The model is run using the original tax wedge measures and the "as if" tax wedge measures. Since the regression results are similar across tax wedge measures, only the results for the "as if" tax wedge using WITHIN WEDGE are reported. Generally, the results using the original tax wedge measure are statistically not as strong as the results using "as if" measures. This confirms the previous assertion that the use of the original tax wedge measure reduces the association

Table 5. Regression Results

Model : IVCHGI $=$ b0 + b1 WEDGECHGi + b2 AVGPAYi + ei

$($ Sample size $=203)$

\begin{tabular}{|c|c|c|c|}
\hline Regressors & $\begin{array}{c}\text { Parameter } \\
\text { Estimate }\end{array}$ & t-statistics & $\begin{array}{l}\text { White } \\
\text { t-statistic }\end{array}$ \\
\hline Intercept & 0.083 & 3.209 & 2.808 \\
\hline WEDGECHG & -2.946 & -3.637 & -3.43 \\
\hline AVGPAY & -0.356 & -4.33 & -2.667 \\
\hline Adjusted R-SQUARE & 0.1582 & & \\
\hline
\end{tabular}

The significance level is based on one-tailed test.

All coefficients are significant at $1 \%$ level 
Utama-Tax Costs and Corporation Dividend Policy

between the dividend change and the increase in the observed tax wedges.

Table 5 presents the regression results, together with the ordinary t-tests and White $t$-statistics that correct for heteroscedasticity. ${ }^{8}$ The result for "as if" WITHIN WEDGE tax wedge measures show that the coefficient for tax wedges change is significantly negative. This verifies that there is significant negative relation between the change in tax wedge and the change in the dividend payout ratio, confirming the indirect impact hypothesis that corporations decrease their dividend payout more when the tax wedge changes are higher.

As expected, the coefficient for $A V G P A Y$ is significantly negative, indicating that higher dividend payout firms generate lower increase in dividend payout ratios over the period.

The intercept is substantially greater than zero, which means that if firms did not experience an increase in tax cost and their payout ratios were close to zero, they would increase their payout ratios. There can be two interpretations for this. The first interpretation is that, in absence of the increase in tax costs, firms that have not paid dividends in the past are more likely to increase dividends in the future. The second interpretation relates to the direct impact hypothesis, which concerns with the elimination of the capital gain tax exclusion after 1986.

Before the 1986 tax act, relative to dividends, capital gains represented a tax advantaged form of distributing earnings because: (1) as opposed to fully taxable dividends, the 60 percent capital gain tax exclusion rate made capital gains only partially taxable, and (2) capital gains were subject to tax only when the gains were realized. Absent non-tax costs, firms would have saved some tax costs by eliminating dividend payments. Since most firms do pay dividends, the non-tax advantages of dividends must outweigh their tax disadvantages.

After 1986, the tax advantage of capital gains was significantly reduced because the capital gain tax exclusion was eliminated. The only tax advantage of capital gains is its value of deferral. Assuming non-tax costs of dividends before and after the act remain constant, and absent an increase in the tax wedge (i.e., tax wedge change $=0$ ), the reduction in the capital gain tax advantage would encourage corporations to increase their dividend payout ratio. This results in the intercept being greater than zero, supporting the direct impact hypothesis.

Further evidence of the direct impact hypothesis is as follows. Firms with average holding periods close to zero would most likely increase their payout ratios because there would be no more tax advantage gained from retaining earnings. Firms with longer holding periods would still have some tax advantages in the form of deferral. Those firms may decrease or increase their payout ratios depending on the relative tax value of deferral versus the non-tax advantages of dividends. As the average holding period of shareholders gets longer, tax deferral becomes more valuable and the firm is less likely to

\footnotetext{
8 The model and other models in equation 6, 7, 8, and 9 are tested for possible heteroscedasticity in the disturbance term using White's general test. The tests for all models conclude that heteroscedasticity persists in all models. To correct for the heteroscedasticity, besides providing the results using ordinary $t$-statistics or Fstatistics, and as suggested by White (1980), I compute the White estimator for the variance matrix of the least squares estimators to arrive at White $t$-statistics. White shows that the White estimator provides a consistent estimator of the variance matrix that is corrected for heteroscedasticity.
} 
increase its dividend payout ratio. Therefore, in the absence of the increase in the tax wedge, as the average holding period of investors (AVHOLD) gets longer, the increase in the dividend payout ratio will be lower. ${ }^{9}$

Further evidence on the indirect impact hypothesis is as follows. The hypothesis suggests that the extent of the relationship between $D I V C H G$ and WEDGECHG depends on the average holding period of shareholders. By reducing dividend payment, firms whose average shareholders have long holding periods save more tax than firms with shareholders having short holding period. Thus, firms with long holding period should have stronger negative associations between DIVCHG and $W E D G E C H G$ than firms with short holding periods.

To investigate these hypotheses, I divide the sample into three sub-samples based on the average holding period over 1984-86. The top quartile contains firms with relatively long holding periods, the next two middle quartiles are grouped as firms with medium-term holding periods, and the bottom quartile contains firms with short holding periods. Then I run a regression of the following model (model 2):

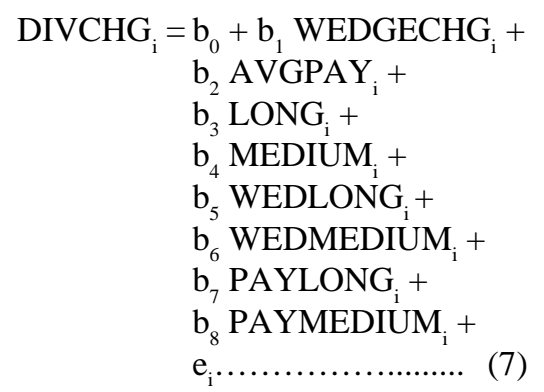

where DIVCHG, WEDGECHG, AVGPAY

and e are as previously defined;

$$
\begin{array}{rl}
\text { LONG }_{\mathrm{i}} & 1 \text { if } \text { AVHOLD }_{\mathrm{i}} \text { is in } \\
& \text { the top quartile, } \\
= & 0 \text { else; } \\
= & 1 \text { if AVHOLD } \\
& \text { the next second in } \\
& \text { third quartiles; } \\
\text { MEDIUM }_{\mathrm{i}} & 0 \text { else; } \\
= & \text { WEDGECHG }_{\mathrm{i}} \mathrm{x} \\
& \text { LONG }_{\mathrm{i}} ; \\
\text { WEDLONG }_{\mathrm{i}} & \\
\text { WEDMEDIUM }_{\mathrm{i}}= & \text { WEDCHG }_{\mathrm{i}} \mathrm{x} \\
& \text { MEDIUM }_{\mathrm{i}} ; \\
\text { PAYLONG }_{\mathrm{i}}= & \text { AVGPAY }_{\mathrm{i}} \mathrm{x} \text { LONG }_{\mathrm{i}} ; \\
\text { PAYMEDIUM }_{\mathrm{i}}= & \text { AVGPAY }_{\mathrm{i}} \mathrm{x} \\
& \text { MEDIUM }_{\mathrm{i}} .
\end{array}
$$

If, in absence of the increase in tax cost, the direct impact hypothesis holds, then $\mathrm{b}_{0}$ is expected to be positive while $b_{3}$ and $b_{4}$ are negative. $b_{3}$ is expected to be more negative than $b_{4}$ since it involves a longer holding period. If the significance of intercept in regression model 1 has nothing to do with the elimination of capital gain exclusion rate, then $b_{3}$ and $b_{4}$ would not be significantly different from zero.

If the indirect impact hypothesis holds, then $b_{5}$ and $b_{6}$ are expected to be negative, where $b_{5}$ is more negative than $b_{6}$. PAYLONG and PAYMEDIUM are included to control for the possible variation in the relation between AVGPAY and $D I V C H G$ across different holding periods.

Table 6 Panel $A$ reports the results of the regression while Panel $B$ presents the results of the relevant tests that are not reported in Panel A. The intercept is significantly positive, indicating that, in the absence of an increase in tax costs, firms

\footnotetext{
${ }^{9}$ As the average holding period gets longer, the increase in the present value of tax deferral is not constant but is becoming smaller. This implies that the relationship between the average holding period and dividend payout may be quadratic and has a half $\mathrm{U}$ shape.
} 
Utama-Tax Costs and Corporation Dividend Policy

Table 6. Regression Results

Model: DIVCHGI $=\mathrm{b}_{0}+\mathrm{b}_{1}$ WEDGECHG $_{\mathrm{i}}+\mathrm{b}_{2}$ AVGPAY $_{\mathrm{i}}+\mathrm{b}_{3}$ LONG $_{\mathrm{i}}+\mathrm{b}_{4}$ MEDIUM $_{i}+b_{5}$ WEDLONG $_{i}+$ $\mathrm{b}_{6}$ WEDMEDIUM $_{\mathrm{i}}+\mathrm{b}_{7}$ PAYLONG $_{\mathrm{i}}+$

$($ Sample size $=203)$

\section{PANEL A}

\begin{tabular}{|c|c|c|c|}
\hline Regressors & $\begin{array}{c}\text { Parameter } \\
\text { Estimate }\end{array}$ & t-statistics & $\begin{array}{c}\text { White } \\
\text { t-statistics }\end{array}$ \\
\hline Intercept & 0.14 & $3.186 * * *$ & $4.17 * * *$ \\
\hline WEDGECHG & -0.289 & -0.241 n.s & $-0.335 \mathrm{n} . \mathrm{s}$ \\
\hline AVGPAY & -0.778 & $-5.875 * * *$ & $-6.812 * * *$ \\
\hline LONG & -0.132 & $-1.954 * *$ & $-1.715 * *$ \\
\hline MEDIUM & -0.061 & -1.065 n.s & $-1.317 *$ \\
\hline WEDLONG & -6.918 & $-3.224 * * *$ & $-2.915 * * *$ \\
\hline WEDMEDIUM & -2.719 & $-1.575 *$ & $-1.686 * *$ \\
\hline PAYLONG & 0.863 & $4.277 * * *$ & $3.193 * * *$ \\
\hline PAYMEDIUM & 0.474 & $2.595 * * *$ & $2.496 * * *$ \\
\hline Adjusted R-SQUARE & 0.242 & & \\
\hline
\end{tabular}

The significance level is based on one-tailed test.

$\mathrm{n} . \mathrm{s}=$ not significant at $10 \%$ level; $*$ = significant at $10 \%$ level; $* *=$ significant at $5 \%$ level; $* * *=$ significant at $1 \%$ level

PANEL B

\begin{tabular}{lccc}
\hline & F Value & & Chisq Value \\
$\begin{array}{l}\text { A.Direct Impact Hypothesis } \\
\begin{array}{l}\text { a. Ho:b3=b4 } \\
\text { Ha:b3<b4 }\end{array}\end{array}$ & \\
B. Indirect Impact Hypothesis & & \\
$\begin{array}{l}\text { a. Ho:b5=b6 } \\
\text { Ha:b5<b6 }\end{array}$ & $3.574 * *$ & \\
\hline
\end{tabular}

The F tests use the ordinary variance covariance matrix while the Chi-square tests use the White corrected variance covariance matrix n.s = not significant at $1 \%$ level; $*=$ significant at $10 \%$ level; $* *=$ significant at $5 \%$ level; $* * *=$ significant at $1 \%$ level 
with short holding periods would increase their payout ratios. $b_{3}$ is significantly negative at 5 percent critical level. On the basis of the ordinary $t$-test, $b_{4}$ is not significant while based on White corrected $t$-statistic, it is marginally significant $(0.05<\mathrm{p}<0.1)$. These results are consistent with the direct impact hypothesis and suggest that, absent an increase in the tax wedge, firms with medium or long holding periods do not increase their payout ratios as much as firms with short holding periods. However, Panel $B$ shows that, although $b_{3}$ is less than $b_{4}$, it is not statistically more negative than $b_{4}$. This result is not consistent with the direct impact hypothesis. In summary, the tests indicate a marginal support for the direct impact hypothesis.

$b_{1}$ is not significantly less than zero. This confirms the hypothesis that for firms that have short holding periods, there is not much tax that can be saved from decreasing payout ratios, and thus, there is weak relation between $D I V C H G$ and $W E D G E C H G . b_{5}$ is significantly negative, indicating that for firms with long holding periods, the negative association between DIVCHG and tax wedge change is stronger than for firms with short holding periods. Although $b_{6}$ is negative at 5 percent level, it is significantly less negative than $b_{5}$ (Table 6 Panel B). For firms with medium holding periods, the negative association between $D I V C H G$ and tax wedge change is stronger than for firms with short holding periods but not as strong as firms with long holding periods. These results strongly support the indirect impact hypothesis. Firms with long holding periods have stronger negative associations between $D I V C H G$ and WEDGECHG than firms with short holding periods or firms with medium holding periods. ${ }^{10}$

\footnotetext{
${ }^{10}$ Model 2 treats $A V H O L D$ as a categorical variable. It assumes that the relationship between $D I V C H G$ and $W E D G E C H G$ is the same within each group. To examine the sensitivity of the results to the classification in model 2, the following tests consider AVHOLD as a continuous variable. Footnote 12 indicates that the relationship between AVHOLD and DIVCHG may not be linear. To investigate this, I run the following regressions:

Model 3:

DIVCHG $_{\mathrm{i}}=\mathrm{b}_{0}+\mathrm{b}_{1}$ WEDGECHG $_{\mathrm{i}}+\mathrm{b}_{2}$ AVGPAY $_{\mathrm{i}}+\mathrm{b}_{3}$ AVHOLD $_{\mathrm{i}}+\mathrm{b}_{4}$ WEDHOLD $_{\mathrm{i}}+$

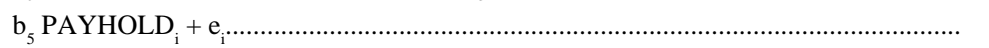

Model 4:

DIVCHG $_{i}=b_{0}+b_{1}$ WEDGECHG $_{i}+b_{2}$ AVGPAY $_{i}+b_{3}$ AVHOLD $_{i}+b_{4}$ AVHOLD $_{i}^{2}+$ $\mathrm{b}_{5}$ WEDHOLD $_{\mathrm{i}}+\mathrm{b}_{6}$ PAYHOLD $_{\mathrm{i}}+\mathrm{e}_{\mathrm{i}}$

where

DIVCHG, WEDGECHG, AVGPAY, AVHOLD and e are as previously defined;

WEDHOLD $_{\mathrm{i}}=$ WEDGECHG $_{\mathrm{i}} \times \mathrm{AVHOLD}_{\mathrm{i}}$

PAYHOLD $_{i}=$ AVGPAY $_{i}$ x AVHOLD

AVHOLD $^{2}=$ AVHOLD $_{\mathrm{i}} \times$ AVHOLD

If the relation between AVHOLD and DIVCHG is linear, then Model 3 holds and $b_{3}$ and $b_{4}$ are expected to be negative. For Model $4, b_{3}$ and $b_{4}$ are expected to be negative and positive respectively since the relation between $D I V C H G$ and $A V H O L D$ is expected to be quadratically negative. $\mathrm{B}_{5}$ is expected to be negative.

Generally, the results are consistent with the results for model 2. Consistent with the indirect impact hypothesis, the coefficients for WEDHOLD in both models are significantly negative at 5 percent. In model 3 , $\mathrm{b}_{3}$ is not significantly less than zero while in model 4 , as expected, $\mathrm{b}_{3}$ and $\mathrm{b}_{4}$ are significantly negative and positive at 5 percent critical level. Thus, it appears that the relation between DIVCHG and AVHOLD is negative but it is not linear, confirming the assertion made in footnote 12 and supporting the direct impact hypothesis.
} 
Utama-Tax Costs and Corporation Dividend Policy

\section{Conclusion}

The study conducts empirical tests of the impact of the 1986 Tax Reform Act on the change in dividend payout ratios of corporations. The results of the tests are consistent with Scholes and Wolfson's assertion that corporations have experienced increased incremental tax costs relative to partnerships after 1986.

The study empirically shows that there is an inverse relationship between the change in tax wedge and the change in dividend payout ratios. The degree of the relationship is stronger for firms with longer average holding periods. In addition, dividend payout ratios tend to increase for firms that do not experience an increase in incremental tax costs and have low payout ratios. There is some evidence that the increase in dividend payout ratios is strongest for firms with short average holding period. These firms increased their payout ratios because there is no more tax advantage from withholding earnings. Lastly, the study reveals that the lower bound and the upper bound tax wedges are subject to measurement bias. The lower bound tax wedge tends to understate the increase of the tax wedge while the opposite conclusion holds for the upper bound tax wedge.

The results seem to have several contributions to researchers. First, since the findings indicate that corporations act to minimize the tax that shareholders paid on dividends, they support the tax disadvantage theory of dividends and show that dividend policies are relevant for minimizing organizational costs. Second, the finding that the relation between the change in dividend payout and the change in tax wedge depends on the investment horizon of shareholders implies that corporations do act in the interest of their shareholders.
Third, the results provide empirical evidence for predictions by Scholes and Wolfson regarding the increase in relative tax costs after the 1986 tax reform act. Fourth, the study provides alternative measurement of the incremental tax costs.

The following are some extensions for future research. First, the study only examines the impact of the tax change on dividend policies of corporations. Stronger evidence may result if the study simultaneously examines alternative responses of firms to the tax law change. The responses include the change in financial leverage and non-dividend distributions. It would also be interesting to investigate whether these responses are a function of investment horizon. Second, the model uses the same personal tax rate for all firms; therefore, it assumes that there is no tax clientele of investors. As an extension of the study, the same model can be applied with the exception that it incorporates different personal tax rates across firms.

\section{APPENDIX: Comparisons of Alternative Tax Wedge Measures}

In Section III.1, I assert that LOWER WEDGE (UPPER WEDGE) tends to understate (overstate) the level of and the increase in tax wedge. On the basis of this assertion, this section investigates whether the level of tax wedge and tax wedge change measured by LOWER WEDGE (UPPER WEDGE) are significantly lower (higher) than those measured by WITHIN $W E D G E$. It also examines whether the alternative measures are highly correlated.

The study calculates the average tax wedge $\left(\mathrm{Wi}^{*}\right)$ for each sample corporation i over two sub-periods, 1984-86 and 1987- 
Table 7. Rank Order and Product Moment Correlations Between Tax Wedge Measures

(Sample, $\mathrm{n}=368$ )

\begin{tabular}{|c|c|c|c|}
\hline \multicolumn{4}{|c|}{ Panel A : 1984-1986 } \\
\hline Tax Wedge Measure & LOWER & WITHIN & UPPER \\
\hline LOWER & 1.0000 & 0.9368 & 0.8908 \\
\hline WITHIN & 0.9312 & 1.0000 & 0.9667 \\
\hline UPPER & 0.8772 & 0.9609 & 1.0000 \\
\hline \multicolumn{4}{|c|}{ Panel B : 1987-1989 } \\
\hline LOWER & 1.0000 & 0.6610 & 0.5534 \\
\hline WITHIN & 0.7734 & 1.0000 & 0.9692 \\
\hline UPPER & 0.6278 & 0.9426 & 1.0000 \\
\hline \multicolumn{4}{|c|}{ Panel C: Tax Wedge Change } \\
\hline LOWER & 1.0000 & 0.8364 & 0.7637 \\
\hline WITHIN & 0.8204 & 1.0000 & 0.9650 \\
\hline UPPER & 0.7039 & 0.9223 & 1.0000 \\
\hline
\end{tabular}

Pearson correlation coefficients are in the upper diagonal and spearman correlation coefficients are in the lower diagonal. All correlation coefficients are significant at 1 percent level.

89 using three alternative tax wedge measures. To get the change in the tax wedge, the difference between these two averages is calculated for each sample corporation $i$ by subtracting $W i^{* 1984-86}$ from $W i^{* 1987-89}$. Then the mean of these differences is calculated.

Spearman rank order and Pearson product moment correlation between measures for $W i^{* 1984-86}, W i^{* 1987-89}$, and the change in the tax wedge are presented in Table 7 for the total sample. The correlation coefficients for $W i^{* 1984-86}, W i^{* 1987-89}$, and the change in the tax wedge show similar results. A comparison of UPPER and WITHIN WEDGE shows the highest rank order and Pearson correlation coefficients.
The reason for high correlation between the measures is that the average holding period of investors is relatively short. The median of the average holding period over 1984-1989 ranges from 1.6 to 2.5 years. As expected, the results show a relatively low degree of correlation between $L O W E R$ $W E D G E$ and UPPER WEDGE. The correlation between $L O W E R$ WEDGE and UPPER WEDGE and between LOWER WEDGE and WITHIN WEDGE for Wi*1987${ }^{89}$ are lower than those for $W i^{* 1984-86}$. After 1986, the capital gain inclusion rate was eliminated (i.e., g increases from 0.4 to 1 ). The lower bound tax wedge does not capture the effect of the elimination. This reduces the correlation between $L O W E R$ 
Utama-Tax Costs and Corporation Dividend Policy

Table 8. Paired t-tests for Tax Wedge Measures

\begin{tabular}{|c|c|c|c|}
\hline & Mean & t-stat & p-value \\
\hline \multicolumn{4}{|c|}{ Panel A : 1984-1986 } \\
\hline UPPER - LOWER & 0.00248 & 3.369 & 0.0004 \\
\hline UPPER - WITHIN & 0.00134 & 4.619 & 0.0001 \\
\hline WITHIN - LOWER & 0.00113 & 1.92 & 0.0278 \\
\hline \multicolumn{4}{|c|}{ Panel B : 1987-1989 } \\
\hline UPPER - LOWER & 0.00535 & 5.608 & 0.0001 \\
\hline UPPER - WITHIN & 0.00169 & 5.788 & 0.0001 \\
\hline WITHIN - LOWER & 0.00366 & 4.822 & 0.0001 \\
\hline \multicolumn{4}{|c|}{ Panel C: Tax Wedge Change } \\
\hline UPPER - LOWER & 0.00287 & 3.058 & 0.0012 \\
\hline UPPER - WITHIN & 0.00035 & 1.08 & 0.1404 \\
\hline WITHIN - LOWER & 0.00253 & 3.18 & 0.0008 \\
\hline
\end{tabular}

p-values are based on one-tailed tests

$W E D G E$ and the two other tax wedge measures.

Table 8 presents the results of paired $t$-tests between the alternative tax wedge measures. For each sample firm, the difference between two measures is calculated for $W i^{* 1984-86}, W i^{* 1987-89}$, and the tax wedge change. Next, the means of the differences are computed and the null hypotheses are the mean differences equal zero. As expected, the results show that LOWER WEDGE is significantly lower than both UPPER and WITHIN WEDGE for $W i^{* 1984-866}, W i^{* 1987-899}$, and the tax wedge change. Thus, the results are consistent with the assertion that LOWER WEDGE provides a lower bound for the level of tax wedge and the change in tax wedge. For
$W i^{* 1984-86}$ and $W i^{* 1987-899}$, UPPER WEDGE is significantly higher than WITHIN $W E D G E$, confirming the proposition that $U P P E R$ WEDGE is an upper bound measure for the level of tax wedge. However, for the tax wedge change, although the sign is positive, UPPER WEDGE is not significantly higher than WITHIN $W E D G E .^{11}$ The reason for the insignificance is that the average holding period of investors is relatively short.

In summary, results of group comparison show that the correlation between alternative measures is relatively high. The paired t-tests show that, on average, LOWER WEDGE is understated while UPPER WEDGE is overstated.

\footnotetext{
${ }^{11}$ The sign test, however, indicates that UPPER WEDGE is significantly greater than WITHIN WEDGE.
} 


\section{References}

Abrutyn, S., and R. Turner. 1990. Taxes and firms' dividend policies: Survey results. National Tax Journal (December): 491-497.

Barclay, M. J. and C. W. Smith. 1995. The determinants of corporate leverage and dividend policies. Journal of Applied Corporate Finance 7 (Winter): 4-19.

Ben-Horim, M., S. Hochman, and P. Palmon. 1987. The impact of the 1986 tax reform act an corporate financial policy. Financial Management 16 (Autumn): 29-35.

Bolster, P. J., and V. Janjigian. 1991. Dividend policy and valuation effects of the tax reform act of 1986. National Tax Journal (December): 511-518.

Brigham, E.F., and L.C. Gapenski. 1987. Intermediate Financial Management. Hinsdale, IL: The Dryden Press.

Brennan, M. 1970. Taxes, market valuation and corporate financial policy. National Tax Journal December: 417-427.

Copeland, T.E., and J.F. Weston. 1992. Financial Theory and Corporate Policy ( $3^{\text {rd }}$ ed.). Reading, Mass: Addison-Wesley Publishing Co.

Gordon, R. J. MacKie-Mason. 1990. Effects of the tax reform act 1986 on corporate financial policy and organizational form. In Joel Slemord (Ed.): Do Taxes Matter? The Impact of the Tax Reform Act of 1986. Cambridge, Mass: The MIT Press.

Greene, W. H. 1993. Econometric Analysis (2 ${ }^{\text {nd }}$ ed.). New York, N.Y.: Macmillan Publishing Co.

Guenther, D.A. 1992. Taxes and organizational form: A comparison of corporations and master limited partnerships. The Accounting Review 67 (January): 17-45.

1990. The Effect of Income Taxes on the Form of Business Entity. Dissertation. University of Washington.

Ibbotson, R.G., and R.A. Sinquefield. 1982. Stocks, Bonds, Bills, and Inflation: The Past and The Future. Charlottesville, VA: Financial Analysts Research Foundation.

Miller, M. and F. Modligiani. 1961. Dividend policy, growth and the valuation of shares. Journal of Business (October): 411-433.

Omer, T.C., K.H. Molloy, and D.A.Ziebart. 1991. Measurement of effective corporate tax rates using financial statement information. The Journal of the American Taxation Association13 (Spring): 57-72.

Papaioannou, G. J. and C. M. Savarese. 1994. Corporate dividend policy response to the tax reform act of 1986. Financial Management 23 (Spring0: 53-56.

Scholes, M.S., and M.A. Wolfson. 1992. Taxes and Business Strategy: A Planning Approach. Englewood Cliffs, NJ: Prentice Hall. 
Utama-Tax Costs and Corporation Dividend Policy

Stickney, C.P., and V.E. McGee. 1982. Effective corporate tax rates - the effect of size, capital intensity, leverage, and other factors. The Journal of Accounting and Public Policy 1 (Winter): 125-152.

White, H. 1980. A heteroscedasticity-consistent covariance matrix estimator and a direct test for heteroscedasticity. Econometrica 48: 817-838.

Wolfson, M. 1988. Taxation, information, and economic organization. Journal of the American Taxation Association 9 (Spring): 13-18. 